\author{
Sh.K. Yeleupayeva*, A.S. Dinmukhamedova \\ L.N. Gumilyov Eurasian National University, Nur-Sultan, Kazakhstan \\ *Corresponding author: a_a_a_shynar@mail.ru
}

\title{
Etiological structure of infectious agents in the urinary tract among children
}

\begin{abstract}
The article presents the results of the research of etiological structure of urinary tract infection among children. Out of the total number of urological and nephrological sick children`s research, it is defined that 283 microorganisms selected from the urine were found. $63.2 \%$ of the total number of children in nephrological department is related to only urological diseases. In recent, there has been an open trend to increase a frequency of diseases of the urinary system. Over the past five years, the number of diseases of the genitourinary system in urban children in Kazakhstan has increased to $65 \%$. The review shows that inflammatory diseases of kidneys and urinary tract take the second place after acute respiratory diseases of upper breathing tract. In this work, it is established that a causative agent of urinary system infection among children is pathogenic, as well as relative-pathogenic microorganisms. As it is shown, the leading etiological agent of uroinfection is Staphylococcus epidermidis (13.9\%), Escherichia coli (12.2\%), Enterobacter cloacae $(7.8 \%)$. In some cases, streptococcus are excreted. Also, there were dominant pathogens of nephroinfection among children such as Escherichia coli (21.1\%), Enterococcus faecalis (9.6\%), Staphylococcus epidermidis (20.1\%). Some types of Candida fungi in the formation of the urinary tract and kidney infection (mostly C.albicans $(9.5 \%)$, C.kruseae $(8.1 \%)$, C.glabrata (5.6\%) pathogens) are observed in the study of urine in children. During the general research, it was found that the etiological agents of urinary system among children consist of a huge microbiological spectrum, especially among children living in urban areas.
\end{abstract}

Keywords: urinary tract infections (UTI), etiology, microflora, accretions, bacteriuria, uropathogen, pyelonephritis, nephrology.

The prevalence of urinary tract infections (UTI) among children remains as an important issue in pediatric nephrology, because this group of diseases takes the first place in the structure of nephropathy compared to other types of glomerulonephritis and kidney disease [1-5].

According to the statistics in recent years of XX century, latent current pyelonephritis (PN) occurs in 2$22 \%$ and asymptomatic forms of bacteriuria have occurred only in 1-3\% of healthy girls, and UTIs are related to the diseases that do not pose a serious threat to children's health [6-8].

And in the recent five years of the XXI century, these indicators have increased from $5 \%$ to $12 \%$ in one city in Kazakhstan, and even the surgical treatment of some recurrent forms of UTIs and structural abnormalities of the urinary tract have caused one of the most complex and dangerous problems in children's lives $[9,10]$.

In spite of the achievements of theoretical and practical nephrology, the world and Kazakhstan are showing high rates of the prevalence of infectious diseases of the urinary system among children. According to statistics, over the recent five years, the incidence of UTIs among children has increased 1.8 times among children under 14 years, and 2 times among adolescents [11]. The reason for this is the first emerging or developing symptoms in the physiology of adolescents in the past, but, at present, UTIs are also visiblein young children and newborns.

Based on the research, it was found that the frequency of nephrological and urological diseases among children and adolescents in the cities of the Irtysh region was due not only to their genetic and medical factors, but also to technogenic pollution of water and air basins [12, 13].

According to this, we are considering a special assessment of the various risk factors that contribute to the development of nephrological and urological diseases of children in the Irtysh region.

The growth rate of statistics shows the highest level for the last three years in the cities on the territory of the Irtysh River (Karaganda city) [14].

While assessing the taxonomic structure of the agents of this pathology in children, it is known that the microorganisms of Enterobacteriaceae (up to 80-90 \%) family takes the basic place in the spectrum of bacterial uropathogens. In particular, E. coli is a definite leader.

The flora of gram-positive cocci (about 10-20\%) takes the second place, mainly were the bacterias of Enterococcus and Staphylococcus family. The third group is a group of relatively rare microorganisms, 
including non-enzymatic gram-negative bacillus (for example, Pseudomonas aeruginosa) and non-sporeforming anaerobes (Bacteroides families) and others [15]. Pathogens of Candida (mostly C. albicans) fungi which cause urinary tract and kidney infections were also found in our research.

The aim of the work: to study the etiological structure of urinary tract infections among children.

\section{Research material and methods}

The work is based on the project from January to December which was conducted between 2017-2018 in Karaganda city. A complex of clinical-laboratory test was conducted in the nephrology department of Regional Children's Clinical Hospital (RCCH) for the patients with inflammatory diseases of urinary system, born and brought up only in the city.

First of all, 283 children of nephrological and urological nature were divided into two groups. Quantitative bacteriological method was used to determine the urinary microflora of patients with inflammatory diseases of the urinary system. Material was taken from the patients 1-2 days before the start of antibiotic therapy. The material obtained from the examined individuals was grafted to Endo, Kalin, Saburo and blood agar media. After isolation of the pure culture and gram staining the microorganisms were identified in a microbiological computer analyzer. Types of microorganisms $10^{4}$ and higher than that were taken as etiological factor excreted from the urine.The obtained data were processed by the method of variation statistics. The degree of reliability of the results was estimated by the probability of difference (P) based on the observed numbers of the relative series $\left(n_{1} n_{2} \ldots\right)$ on the Student's attribute.

\section{The results of research and discussion}

283 cultures of microorganisms excreted from the urine of sick children of urological and nephrological nature were studied. In general, $63.2 \%$ of sick children in the nephrology department were registered only with urological diseases.

The urinary microflora of 179 children with urological symptoms in the nephrology department of Karaganda in 2017-2018 is given in Table 1.

Etiological structure of the urinary microflora of children with urological diseases in the nephrology department

\begin{tabular}{|c|l|c|c|}
\hline \multirow{2}{*}{$№$} & \multirow{2}{*}{ Excreted microorganisms } & \multicolumn{2}{|c|}{ January - December } \\
\cline { 3 - 4 } & & abs & $\%, \mathrm{M} \pm \mathrm{m}$ \\
\hline 1 & Staphylococcus aureus & 4 & $2.2 \pm 1.1$ \\
\hline 2 & Staphylococcus epidermidis & 25 & $13.9 \pm 2.5$ \\
\hline 3 & Staphylococcus saprophyticus & 9 & $5.02 \pm 1.6$ \\
\hline 4 & Enterococcus faecium & 11 & $6.1 \pm 1.7$ \\
\hline 5 & Enterococcus faecalis & 12 & $6.7 \pm 1.8$ \\
\hline 6 & Escherichia coli & 22 & $12.2 \pm 2.4$ \\
\hline 7 & Enterobacter aerogenes & 13 & $7.2 \pm 1.9$ \\
\hline 8 & Enterobacter agglomerans & 6 & $3.3 \pm 1.3$ \\
\hline 9 & Enterobactersakazakii & 2 & $1.1 \pm 0.8$ \\
\hline 10 & Proteus mirabilis & 2 & $1.1 \pm 0.8$ \\
\hline 11 & Proteus aerogenosa & 1 & $0.5 \pm 0.5$ \\
\hline 12 & Klebsiella pneumoniae & 1 & $0.5 \pm 0.5$ \\
\hline 13 & Klebsiella pneumoniae & 2 & $1.1 \pm 0.8$ \\
\hline 14 & Enterobactercloacae & 14 & $7.8 \pm 2.0$ \\
\hline 15 & Hafnia alvei & 3 & $1.6 \pm 0.9$ \\
\hline 16 & Pseudomonas aeruginosa & 1 & $0.5 \pm 0.5$ \\
\hline 17 & Citrobacter freundii & 1 & $0.5 \pm 0.5$ \\
\hline 18 & Candida albicans & 22 & $12.2 \pm 24$ \\
\hline 19 & Candida kruseae & 15 & $8.3 \pm 2.1$ \\
\hline 20 & Candida glabrata & 12 & $6.7 \pm 1.8$ \\
\hline 21 & Moraxella catarrhalis & $\mathbf{1 7 9}$ & $0.5 \pm 0.5$ \\
\hline Total & & $\mathbf{1 0 0}$ \\
\hline & &
\end{tabular}


The etiological structure of the urinary microflora of sick children in urological discussion was determined by 21 species, as shown in Table 1 below. Enterococcus faecalis - $6.8 \%$, Enterococcus faecium - $6.2 \%$, Escherichia coli - $12.5 \%$, Staphylococcus epidermidis - $14 \%$, Enterobacter aerogenes - 7.2\%, Candida glabrata - 6.7\%, Candida kruseae - $8.3 \%$, Candida albicans - $12.3 \%$, Enterobacter cloacae - $7.8 \%$ are related to dominant species.

The spectrum of microflora isolated from the urine of sick children with urological symptoms is shown in Figure 1.

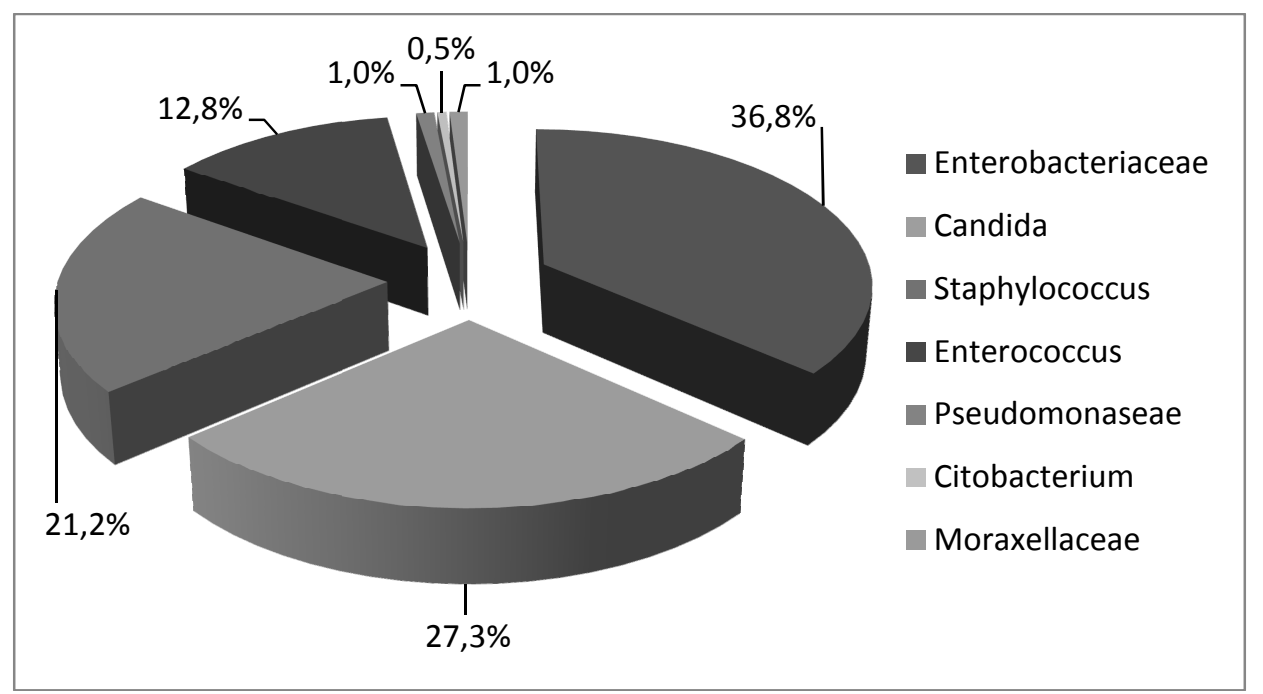

Figure 1. Spectrum of microflora excreted from the urine of sick children with urological symptoms

In the picture below, the first place was taken by the representatives of the family Enterobacteriaceae excreted from the urine of children with urological diseases - $36.8 \%$. It shows this number out of the total quantity of excreted microorganisms, Enterococcus relative representatives - 12.8\%, Staphylococcus relatives - $21.2 \%$. Non-fermented gram-negative bacterias taken from the urine of patients with uroinfection were excreted in the amount of $36.8 \%$, and Pseudomonas aeruginosa comprised $1.11 \%$ out of the total number of non fermenting gram negative bacteria (FGNB). $27.3 \%$ is related to Candida fungi.

And the urinary microflora of children with nephrological diseases in the children's clinical hospital in Karaganda is given in Table 2. One of the peculiarity of this is the indicators of microbiotic spectrum of children with impaired renal function and those treated for congenital renal insufficiency. The etiological structure of the urinary microflora of children with nephrological diseases in 19 forms is shown in the Table 2 .

Etiological structure of the urinary microflora of children with nephrological diseases

\begin{tabular}{|c|l|c|c|}
\hline \multirow{2}{*}{$№$} & \multirow{2}{*}{ Excreted microorganisms } & \multicolumn{2}{|c|}{ January - December } \\
\cline { 3 - 4 } & & abs & $\%, \mathrm{M} \pm \mathrm{m}$ \\
\hline 1 & \multicolumn{1}{|c}{2} & 3 & 4 \\
\hline 1 & Staphylococcus aureus & 2 & $1.9 \pm 1.3$ \\
\hline 2 & Staphylococcus epidermidis & 21 & $20.1 \pm 3.9$ \\
\hline 3 & Staphylococcus saprophyticus & 3 & $2.8 \pm 1.6$ \\
\hline 4 & Enterococcus faecium & 1 & $0.9 \pm 0.9$ \\
\hline 5 & Enterococcus faecalis & 10 & $9.6 \pm 2.8$ \\
\hline 6 & Escherichia coli & 22 & $21.1 \pm 4.0$ \\
\hline 7 & Enterobacter aerogenes & 4 & $3.8 \pm 1.9$ \\
\hline 8 & Enterobacter agglomerans & 2 & $1.9 \pm 1.3$ \\
\hline 9 & Enterobactersakazakii & 4 & $3.8 \pm 1.9$ \\
\hline 10 & Enterococcus durans & 3 & $2.8 \pm 1.6$ \\
\hline 11 & Proteus mirabilis & 1 & $1.9 \pm 1.3$ \\
\hline 12 & Klebsiella pneumoniae & & $0.9 \pm 0.9$ \\
\hline
\end{tabular}


Continuation of $\mathrm{Tab}$ e 2

\begin{tabular}{|c|l|c|c|}
\hline 1 & \multicolumn{1}{|c|}{2} & 3 & 4 \\
\hline 13 & Enterobactercloacae & 5 & $4.8 \pm 2.0$ \\
\hline 14 & Hafnia alvei & 2 & $1.9 \pm 1.3$ \\
\hline 15 & Pseudomonas aeruginosa & 4 & $3.8 \pm 1.9$ \\
\hline 16 & Citrobacter freundii & 1 & $0.9 \pm 0.9$ \\
\hline 17 & Candida albicans & 5 & $4.8 \pm 2.0$ \\
\hline 18 & Candida kruseae & 8 & $7.6 \pm 2.6$ \\
\hline 19 & Candida glabrata & 4 & $3.8 \pm 1.9$ \\
\hline \multicolumn{2}{|l|}{ Total } & $\mathbf{1 0 4}$ & $\mathbf{1 0 0}$ \\
\hline
\end{tabular}

In general, 104 cultures were studied. Enterococcus faecalis - 9.6\%, Escherichia coli $-21.1 \%$, Staphylococcus epidermidis - $20.1 \%$, Candida glabrata $-6.7 \%$, Candida kruseae $-7.7 \%$, Candida albicans $-4.8 \%$, Enterobacter cloacae $-4.8 \%$ are related to dominant species.

Figure 2 shows the spectrum of microflora isolated from the urine of children with nephrological diseases.

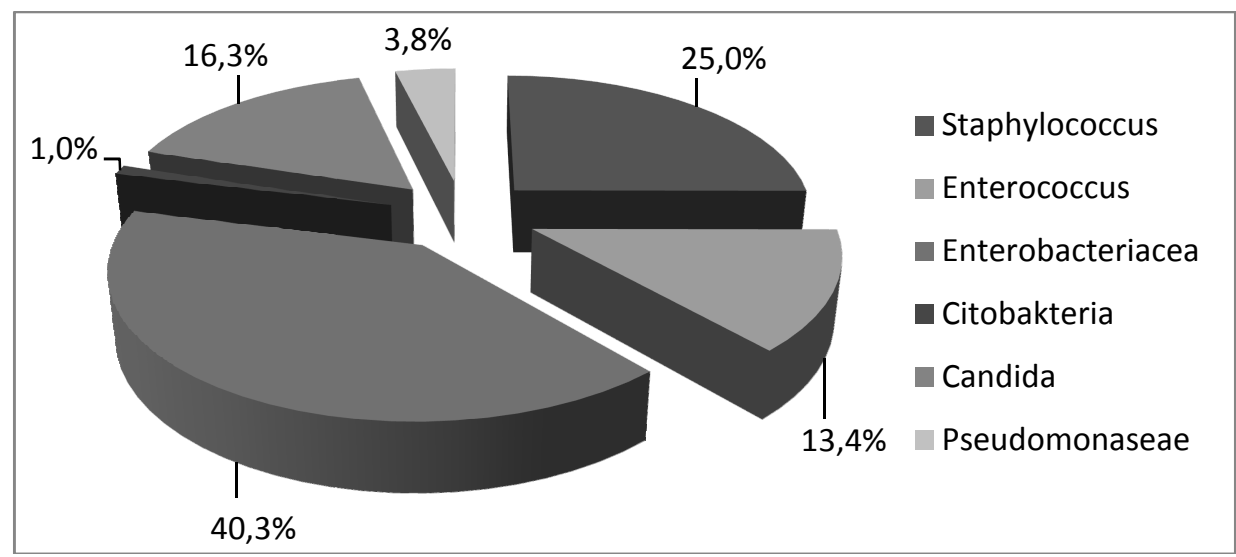

Figure 2. Spectrum of microflora isolated from the urine of children with nephrological diseases

As it is shown in Figure 2, $40.3 \%$ of Enterobacteriaceae family takes the first place to be excreted from the urine of children with nephrological symptoms. Enterococcus takes the second place, $13.4 \%$ of the total number of excreted microorganisms is related to its fraction. 26 cultures were included in Staphylococcus relative, it comprised $25.1 \%$. Fungi are separated in the amount of $16.3 \%$.

\section{Conclusion}

Thus, the research revealed that out of a total of 283 cultures are divided into two sections, urological and nephrological, the leading of urinary tract infections can be pathogenic, as well as relative-pathogenic microorganisms to etiological agents. In our research, the etiological structure of the pathogens of urinary tract infections of children was the leading agent Staphylococcus epidermidis (16.2\%), Escherichia coli (15.5\%), Enterococcus faecalis (7.7 \%), Enterobacter cloacae (4.9\%), Enterobacter aerogenes (4.5\%).

According to world statistics, the first row of urinary tract infections Escherichia coli accounts for $90 \%$, Enterococcus 5-7\%, Klebsiella 4-6\%. And our research shows that the class of bacilli is dominated by the bacterium Staphylococcus epidermidis. It is a conditionally pathogenic bacterium that causes purulent infection of the skin mucosa of the urinary system.

\section{References}

1 Борисова Т.П. Инфекция мочевой системы у детей. Ч. 1 / Т.П. Борисова, И.В. Багдасарова // Клиническая медицина. - 2014. - T. 3, № 1. - C. 20-24.

2 Захарова И.Н. Инфекция мочевой системы у детей и современные представления об этиологии / И.Н. Захарова // Нефрология и диализ. - 2015. - № 1- С. 48-54. 
3 Ешимова С. Антибиотикочувствительность штаммов Enterococcus faecalis, выделенных от больных с инфекциями мочевыводящей системы / С. Ешимова, Ж. Тулегенова, Н. Кенжебаева, А. Динмухамедова // Клиническая медицина Казахстана. - 2015. - № 4 (38). - С. 46-49.

4 Статистика здравоохранения Республики Казахстан. 2019 // Инфекционная заболеваемость населения Республики Казахстан в 2017-2018 годах. - Нур-Султан, 2019.

5 Кузнецова А.А. Водно-солевой обмен и функции почек у детей при целиакии и хроническом гастродуодените / А.А. Кузнецова, М.О. Ревнова, Ю.В. Наточин // Педиатрия. - 2015. - Т. 2, № 5. - С. 27-31.

6 Клейн С.В. Приоритетные факторы риска питьевой воды и связанный с этим экономический ущерб / С.В. Клейн, С.А. Вековшинина, А.С. Сбоев // Гигиена и санитария. - 2016. - № 1. - С. 10-14.

7 Сафина А.И. Формирование хронической болезни почек у детей раннего возраста, родившихся глубоко недоношенными / А.И. Сафина, Г.А. Абдуллина, М.А. Даминова // Педиатрия. — 2016. — № 95 (5). — С. 17-21.

8 Писклаков А.В. Показатели профилометрии уретеровезикального соустья при пузырно-мочеточниковом рефлюксе у детей с нейрогенной дисфункцией мочевого пузыря / А.В. Писклаков, А.С. Шевляков // Педиатрия. - 2016. - № 95 (5). C. $132-135$.

9 Корсунский А.А. Комплексное лечение рецидивирующего цистита при нейрогенной дисфункции мочевого пузыря у девочек / А.А. Корсунский, Н.Б. Гусева, Е.Я. Гаткин, И.А. Корсунский // Педиатрия. — 2017. — № 96 (1). — С. $209-211$.

10 Васильев А.О. Изменение микрофлоры мочи у пациентов с мочекаменной болезнью / А.О. Васильев, А.В. Говоров, А.А. Ширяев // Урология. - 2018. - № 6. - С. 26-31.

11 Дутов В.В. Оценка бактериологического анализа мочи у пациентов с длительным дренированием мочевого пузыря / В.В. Дутов, С.Ю. Буймистр, Е.В. Русанова // Урология. — 2018. — № 6. - С. 32-36.

12 Акбар М. Урологические осложнения после трансплантации почки / М. Акбар // Клиническая медицина Казахстана. - 2018. - № 3 (49). - С. 24-27.

13 Ли В. Механизмы повреждения клеток крови и почек при экзогенных токсических нефропатиях / В. Ли, Л. Демичук // Клиническая медицина Казахстана. — 2019. — № 1 (51). — С. 21-26.

14 Сизонов В.В. Результаты лечения новорожденных с постренальной анурией, обусловленной обструкцией грибковыми безоарами верхних мочевыводящих путей / В.В. Сизонов, В.И. Дубров, Н.Р. Акрамов, Н.В. Марков, И.М. Каганцов, А.Х-А. Шидаев // Педриатрия и урология. - 2020. — № 1. - С. 81-85.

15 Палагин И.С. Состояние антибиотикорезистентности возбудителей внебольничных инфекций мочевыводящих путей в России, Беларуси и Казахстане: результаты многоцентрового международного исследования «Дармис-2018» / И.С. Палагин, М.В. Сухорукова, А.В. Дехнич, М.В. Эйдельштейн // Урология. - 2020. — № 1. — С. $19-31$.

\title{
Ш.К. Елеупаева, А.С. Динмухамедова
}

\section{Балалар арасында зәр шығару жолдарындағы инфекциялық қоздырғыштардың этиологиялық құрылымы}

\begin{abstract}
Мақалада балалар арасында зәр шығару жолдары инфекциясының этиологиялық құрылымының зерттеу нәтижелері көрсетілген. Жалпы зерттелінген урологиялық және нефрологиялық науқас балалар несептерінен бөлініп алынған 283 микроорганизм культуралар ішінде жалпы нефрология бөліміндегі науқас балалардың 63,2 \%-ы тек урологиялық ауруға шалдыққандар қатарында екені белгілі болды. Соңғы жылдары несеп шығару жүйесі мүшелерінің ауруға шалдығу жиілігінің өсуіне ашық тенденция байқалған. Соңғы бес жыл аралығында Қазақстанда несеп-жыныстық жүйесінің ауру саны қалада тұратын балаларда 65 \% дейін өскен. Бүйрек және несеп жолдарының қабыну аурулары беткі тыныс алу жолдарының өткір респираторлы ауруларынан кейін екінші орынды алатындығы бойынша шолу жасалынған. Бұл зерттеуде балалар арасында несеп шығару жүйесі инфекциясының қоздырғышы патогенді, сонымен бірге, шартты-патогенді микроорганизмдердің бола алатыны анықталынған. Көрсетілгендей, уроинфекцияның жетекші этиологиялық агенті Staphylococcus epidermidis (13,9\%), Escherichia coli (12,2\%), Enterobacter cloacae (7,8\%) болып табылады. Кей жағдайда ғана стрептококкалар бөлініп алынған. Сонымен қатар балалар арасында нефроинфекцияның доминантты қоздырғышы Escherichia coli (21,1\%), Enterococcus faecalis (9,6\%), Staphylococcus epidermidis (20,1%) болып шықты. Зәр шығару жолдары мен бүйрек инфекциясының қалыптасуында Candida саңырауқұлақтарының кейбір түрлері (көбінесе C. albicans (9,5 \%), C. kruseae $(8,1 \%)$, . glabrata (5,6 \%) қоздырғыштары) балалар несебін зерттеулер кезінде айтарлықтай кездесіп отырғаны байқалған. Жалпы зерттеу барысы кезінде балалар арасындағы зәр шығару жүйесінің этиологиялық қоздырғыштарының орасан үлкен микробиоталық спектрден тұратыны, әсіресе қалалық аумақта тұратын балалар арасында жиі кездесетін түрлері анықталған.
\end{abstract}

Кілm сөздер: зәр шығару жолдары инфекциясы (ЗШЖИ), этиология, микрофлора, өсінділер, бактериурия, уропатоген, пиелонефрит, нефрология. 


\title{
Ш.К. Елеупаева, А.С. Динмухамедова \\ Этиологическая структура инфекционных возбудителей мочевыводящих путей среди детей
}

\begin{abstract}
В статье представлены результаты исследования этиологической структуры инфекций мочевыводящих путей у детей. Из 283 микроорганизмов, выделенных из мочи детей с урологическими и нефрологическими заболеваниями, 63,2 \% детей с общей нефрологией были диагностированы только с урологическими заболеваниями. В последние годы наметилась четкая тенденция к увеличению заболеваемости мочевыделительной системы. За последние пять лет в Казахстане количество заболеваний мочеполовой системы городских детей возросло до 65 \%. Воспалительные заболевания почек и мочевыводящих путей считаются вторыми после острых респираторных заболеваний верхних дыхательных путей. В этом исследовании было установлено, что возбудителем инфекций мочевыводящих путей у детей могут быть как патогенные, так и условно-патогенные микроорганизмы. Показано, что основными этиологическими агентами уроинфекции являются Staphylococcus epidermidis (13,9\%), Escherichia coli (12,2\%), Enterobacter cloace (7,8 \%). В некоторых случаях стрептококки были изолированы. Кроме того, доминирующими возбудителями нефроинфекции среди детей выступили Escherichia coli (21,1 \%), Entercoccus faecalis (9,6 \%), Staphylococcus epidermidis (20,1 \%). Обнаружено, что возбудители C. albicans $(9,5 \%)$, C. kruseae $(8,1 \%)$, C. glabrata $(5,6 \%)$ значимы в моче детей. В целом, исследования показали, что мочевыводительная система у детей состоит из огромного количества этиологических патогенов, особенно среди детей, живущих в городских районах.
\end{abstract}

Ключевые слова: инфекции мочевыводящих путей, этиология, микрофлора, штаммы, бактериурия, уропатогены, пиелонефрит, нефрология.

\section{References}

1 Borisova, T.P., \& Bagdasarova, I.V. (2014). Infektsiia mochevoi sistemy u detei. Chast 1. [Urinary tract infection of children. Part 1]. Klinicheskaia meditsina - Clinical medicine, 3, 1, 20-24 [in Russian].

2 Zakharova, I.N. (2015). Infektsiia mochevoi sistemy u detei i sovremennye predstavleniia ob etiolohii [Infection of the urinary system of children and modern ideas about the etiology]. Nefrolohiia i dializ - Nephrology and dialysis, 1, 48-54 [in Russian].

3 Eshimova, S., Tulegenova, Zh., Kenzhebaeva, N., \& Dinmukhamedova, A. (2015). Antibiotikochuvstvitelnost shtammov Enterococcus faecalis, vydelennykh ot bolnykh s infektsiiami mochevyvodiashchei sistemy [Antibiotic sensitivity of strains Enterococcus faecalis, isolated from patients with urinary tract infections]. Klinicheskaia meditsina Kazakhstana - Clinical Medicine of Kazakhstan, 4, 38, 46-49 [in Russian].

4 Statistika zdravookhraneniia Respubliki Kazakhstan - 2019 [Health statistics of the Republic of Kazakhstan - 2019]. (2019). Infektsionnaia zabolevaemost naseleniia Respubliki Kazakhstan v 2017-2018 hodakh - Infectious diseases of the population of the Republic of Kazakhstan in 2017-2018. Nur-Sultan [in Russian].

5 Kuznetsova, A.A., Revnova, M.O., \& Natochin, Yu.V. (2015). Vodno-solevoi obmen i funktsii pochek u detei pri tseliakii i khronicheskom hastroduodenite [Water-salt metabolism and renal function in children with coeliac disease and chronic gastroduodenitis]. Pediatriia - Pediatrics, 2, 5, 27-31 [in Russian].

6 Klein, S.V., Vekovshinina, S.A. \& Sboev, A.S. (2016). Prioritetnye faktory riska pitevoi vody i sviazannyi s etim ekonomicheskii ushcherb [Priority risk factors for drinking water and associated economic damage]. Hihiena i sanitariia - Hygiene and sanitation, 1, 10-14 [in Russian].

7 Safina, A.I., Abdullina, G.A. \& Daminova, M.A. (2016). Formirovanie khronicheskoi bolezni pochek u detei ranneho vozrasta, rodivshikhsia hluboko nedonoshennymi [The formation of chronic kidney disease in young children born deeply premature]. Pediatriia - Pediatrics, 95, 5, 17-21 [in Russian].

8 Pisklakov, A.V. \& Shevliakov, A.S. (2016). Pokazateli profilometrii ureterovezikalnoho soustia pri puzyrnomochetochnikovom refliukse u detei s neirohennoi disfunktsiei mochevoho puzyria [Profilometry of ureterovesical anastomosis in case of vesicoureteral reflux in children with neurogenic bladder dysfunction]. Pediatriia - Pediatrics, 95, 5, 132-135 [in Russian].

9 Korsunskii, A.A., Guseva, N.B., Gatkin, E.Ya., \& Korsunskii, I.A. (2017). Kompleksnoe lechenie retsidiviruiushcheho tsistita pri neirohennoi disfunktsii mochevoho puzyria u devochek [Complex treatment of recurrent cystitis with neurogenic bladder dysfunction in girls]. Pediatriia - Pediatrics, 96, 1, 209-211 [in Russian].

10 Vasilev, A.O., Govorov, A.V., \& Shiriaev, A.A. (2018). Izmenenie mikroflory mochi u patsientov s mochekamennoi bolezniu [Changes in the urinary microflora in patients with urolithiasis]. Urolohiia - Urology, 6, 26-31 [in Russian].

11 Dutov, V.V., Buimistr, S.Yu., \& Rusanova, E.V. (2018). Otsenka bakteriolohicheskoho analiza mochi u patsientov s dlitelnym drenirovaniem mochevoho puzyria [Evaluation of bacteriological analysis of urine in patients with prolonged bladder drainage]. Urolohiia - Urology, 6, 32-36 [in Russian].

12 Akbar, M. (2018). Urolohicheskie oslozhneniia posle transplantatsii pochki [Approach to urological complications early post renal transplant]. Klinicheskaia meditsina Kazakhstana - Clinical Medicine of Kazakhstan, 3, 49, 24-27 [in Russian].

13 Li, V., \& Demichuk, L. (2019). Mekhanizmy povrezhdeniia kletok krovi i pochek pri ekzohennykh toksicheskikh nefropatiiakh [Mechanisms of blood cells and kidney lesion in exogenous toxic nephropathies]. Klinicheskaia meditsina Kazakhstana - Clinical Medicine of Kazakhstan, 1, 51, 60-64 [in Russian]. 
14 Sizonov, V.V., Dubrov, V.I., Akramov, N.R., Markov, N.V., Kagantsov, I.M., \& Shidaev, A.Kh-A. (2020). Rezultaty lecheniia novorozhdennykh s postrenalnoi anuriei, obuslovlennoi obstruktsiei bezoarami verkhnikh mochevyvodiashchikh putei [The results of treatment of newborns with postrenal anuria due to obstruction of the upper urinary tract with fungal bezoars]. Pediatriia $i$ urolohiia - Pediatrics and urology, 1, 81-85 [in Russian].

15 Palagin, I.S., Sukhorukova, M.V., Dekhnich, A.V., \& Eidelshtein, M.V. (2020). Sostoianie antibiotikorezistentnosti vozbuditelei vnebolnichnykh infektsii mochevyvodiashchikh putei v Rossii, Belarusi i Kazakhstane: rezultaty mnohotsentrovoho mezhdunarodnoho issledovaniia «Darmis-2018» [The status of antibiotic resistance of community-acquired urinary tract infections in Russia, Belarus and Kazakhstan: results of the multicenter international study «Darmis-2018»]. Urolohiia - Urology, 1, 19-31 [in Russian]. 